\title{
Selection of a mini-grid business model for developing countries using CRITIC- TOPSIS with interval type-2 fuzzy sets
}

\author{
Desmond Eseoghene Ighravwe ${ }^{a^{*}}$ and Moses Olubayo Babatunde ${ }^{b}$
}

\begin{tabular}{l}
${ }^{a}$ Ladoke Akintola University of Technolo \\
${ }^{b}$ University of Lagos, Nigeria \\
\hline C H R O N I C L E \\
\hline Article history: \\
Received September 12, 2017 \\
Received in revised format: \\
January 8, 2017 \\
Accepted January 11, 2018 \\
Available online \\
January 12, 2018 \\
\hline Keywords: \\
CRITIC \\
TOPSIS \\
WASPAS \\
IT2FSs \\
Mini-grid \\
Business model
\end{tabular}

\section{Introduction}

Energy study is an inter-disciplinary study, it involves disciplines such as engineering, political science, environmental science, medical and management science. These disciplines constitute the pillars that supports energy study. Management science input to energy study is the key to successfully execute an energy plan. This is because it aids proper evaluation of technology selection, power distribution, energy tariff, energy business model and energy sustainability. Technology selection is a major issue among researchers and practitioners. Recent efforts are geared towards moving from non-renewable

\begin{abstract}
A B S T R A C T
The growth in renewable energy study has resulted in the expansion of mini-grids projects across different communities in developing countries. However, there is a need to ensure that a suitable business model is selected during the provision of mini-grid services in developing countries. This study presents a framework for ranking mini-grid business models. The proposed framework is a multi-criteria multi-decision (MCMD) making tool. The framework combines Criteria Importance Through Inter-criteria Correlation (CRITIC), TOPSIS (Technique for Order Performance by Similarity to Ideal Solution) and WASPAS (weighted aggregated sum product assessment) methods. An interval type-2 fuzzy sets (IT2FSs) is used to convert the responses from decision-makers into crisp values. The applicability of the proposed framework was tested using Nigeria as a case study. Four potential mini-grid (private, government, community-based and public-private) business models for the case study were methods showed that electricity traffic and energy demand were the least and the most important criteria, respectively, for selecting a mini-grid business model. The results obtained showed that the best mini-grid model was a private model using a TOPSIS framework. A WASPAS framework ranked the community-based business model as the best model. This study results showed mini-grid business models in developing countries should be either private or community-based business models.
\end{abstract}


energy sources to renewable energy sources (Ulsrud et al., 2011). This paradigm shift is vital in order to preserve our environment and reduce depletion of non-renewable sources.

The growth in renewable energy sources has improved global access to electricity (Alzola et al., 2009; Ulsrud et al., 2011). This is more evident in developing countries where issues around electric power generation is epileptic. The lack of ingenious technology to generate electric power is among the factors responsible for this problem. Electricity generation technology is often required for the conversion of fossil fuels to electric power. This has made most developing countries dependent on foreign technology. In order to solve this problem, mini-grid electric power system is now dominating most rural communities in developing countries.

This development is due to the ease of using local technology to generate energy from renewable energy sources. Solar and wind powered mini-grid energy systems have benefited from local technology (Kirubi et al., 2009; Ulsrud et al., 2011). This has made them the most sort after sources for mini-grid energy systems in developing countries by business owners. The decision to select a mini-grid energy source is dependent on the type of mini-grid business model and technology that are suitable for a particular location (Bonaccorsi et al., 2006). The selection of mini-grid business models for a community using multi-criteria analysis has not received adequate attention in multi criteria situations (Polatidis et al., 2006; Tsoutsos et al., 2009; Sun, 2010; Sindhu et al., 2016). However, to fully understand the underlying decision for selecting a particular technology or business model, multicriteria are used to analyse relevant information (Knuckles, 2016).

Relevant information for a mini-grid problem is often expressed in linguistic terms. This means to successfully analyse a mini-grid problem, scientific models that has the capacity to handle linguistic terms are required. This creates a means of converting linguistic expressions into crisp values. Despite the availability of several scientific models that have the capacity to address this problem, there is sparse information on how to select mini-grid business models using these tools. Thus, there is a need to bridge this important knowledge gaps. In view of this, the current study presents a framework that addresses this gap. The framework is an integrated model that combines CRITIC (Criteria Importance Through Inter-criteria Correlation) and TOPSIS (Technique for Order Performance by Similarity to Ideal Solution) methods. These methods have the capacity to analyse linguistic terms and multi-criteria information (Chen, 2000; Kaya \& Kahraman, 2011). The multi-criteria information for the mini-grid business model selection problem is analysed using interval type 2 fuzzy sets (IT2FS). Thus, the aim of this study is to apply TOPSIS as an approach to the selection of a mini-grid business model for a developing economy. The performance of the proposed framework is compared with WASPAS (Weighted Aggregated Sum Product Assessment) method.

The remaining parts of this study are organised as follows: Section 2 presents literature on energy study, while the proposed framework is contained in section 3. An illustrative example of the proposed framework performance is presented in section 4. The conclusions of the study and areas of further research are contained in section 5 .

\section{Literature}

\subsection{Energy challenges}

Mini-grids are combinations of electric generators, energy storage and distribution equipment interconnected to supply power to isolated consumers. Its power generation scheme ranges from $5 \mathrm{~kW}$ to $10 \mathrm{MW}$ (Anderson et al., 1999; Lasseter, 2002; Franz et al., 2014; African Development Bank Group, 2016). Mini-grid is usually designed to operate either in isolation or sometimes connected to the national utility transmission grid. When operated in isolation, they are intended to satisfy the electric load demand of a limited number of consumers (Hatziargyriou et al., 2007; Katiraei et al., 2005). This 
is however different from Nano-grids which is basically composed of few solar home system (SHS) without any distribution network (Burmester et al., 2017; Akinyele, 2017).

Mini-grid functions under normal operating conditions as a sub-component of a centralised grid system with isolation occurrs for cases where the power quality or the reliability is compromised. For instance, when a blackout occurs on the central grid system, the mini-grid is islanded to serve the load demand of localised consumers. Depending on the resource availability, mini-grid generators are composed of fossil and renewable power plants, and storage system with operational AC voltage ranging between 220- 415V (Rolland, 2011; Tenenbaum et al., 2014).

This type of energy technology helps to improve rural dwellers standard of living. Also, it brings about positive social impact by encouraging and harmonising local content in the decision process of adopting new energy systems. It has been identified to be economically viable in the electrification of remote communities (Akinbulire et al., 2014). The World Bank and the International Energy Agency reiterate that grid extension is the most economically viable alternative for urban electrification and about 30 percent of remote communities (World Bank, 2008). They further suggested that it will be economical to power the remaining $70 \%$ of the rural communities either with mini-grids or small stand-alone offgrid generation. When powered by renewable energy resources, mini-grids provide electricity at a cheaper cost as compared to conventional generators. IEA predicts that more than 50 per cent of the rural residents presently lacking adequate access to electricity will be better catered for using minigrids (Bhattacharyya \& Palit, 2014; IEA, 2014; African Development Bank Group, 2016).

To effectively manage energy distributions from a mini-grid, there is a need to adopt an appropriate mini-grid business model for a community (Knuckles, 2016). Several benefits and opportunities have been identified with the adoption of a mini-grid system. This ranges from techno-economical to environmental benefits. Due to its modular nature, mini-grids have the tendency to increase the reliability of electricity supply as compared to the complex centralised utility grid (Krause \& Nordstrom, 2004). Furthermore, its small-scale architecture and localized physical infrastructure ownership make equipment management easier. This consequently reduces technical and non-technical losses commonly associated with the centralised grid network. The improved reliability of the minigrid lowers the total cost of the mini-grid over its lifespan and the availability of power for cases that experience centralized grid system failure (Krause \& Nordstrom, 2004).

A mini-grids has the potential to provide a platform for the construction of power system networks that are easily adaptable to the centralized grid during network expansion planning programmes. This has motivated investors who are leveraging on the declining cost of renewable energy technologies. Also, the skyrocketing cost of conventional fuel makes mini-grid business attractive to investors in developing countries (Couture \& Gagnon, 2010). Though, the efficacy of mini-grid in improving access to electricity has been acknowledged, still the rate of adoption in many developing countries remains low. However, countries such as China (with approximately 60,000 mini-grid projects) and Nepal, India, Vietnam, and Sri-Lanka (with between 100 to 1000 mini-grids) each has made tremendous progress in the adoption of mini-grids (Martinot et al., 2002).

The majority of the projects in these countries are composed of either diesel or hydro generation plants that are managed by government institutions. Some of the causes of the low implementation level of mini-grids can be categorized into technical, social-political and economic. This low implementation results from inadequate or lack of proper maintenance culture of equipment, use of substandard technology and the shortage of indigenous expertise in the maintenance of the mini-grid as well as inadequate funding to sustain the project over its lifespan (Bhattacharyya \& Palit, 2014; Tenenbaum et al., 2014). Access to funds is also a barrier to mini-grid implementation in rural communities. Government policies are also influential in future investment in mini-grids projects. This will help to determine the best business model suitable for a particular community. The development of schemes 
without attention to developing supplementary programmes that address issues such as market access, small medium enterprise (SME) development and financing limit the success of mini-grid projects (Rolland, 2011). Therefore, to sustain mini-grid projects, attention should be given to the selection of mini-grid business model, especially in developing countries.

The huge upfront investment cost is a major barrier to mini-grid business in rural communities across the globe. This is because the initial capital for setting up the renewable system is usually far greater than that of its conventional alternative such as diesel-powered generators (Couture \& Gagnon, 2010). Hence, putting together a sustainable financial base for a mini-grid can be difficult despite the emergence of efficient financial analysis tools. Financial schemes for a mini-grid project should be designed to accommodate income generating techniques to enhance sustainability. In other words, the project should be able to pay back within a reasonable time frame. This can be achieved by "setting realistic tariffs for the consumers despite potential equality implications" (GVEP International, 2011).

In many developing economies, mini-grid projects are implemented through the use of grants, government funding and subsidies (Barnes \& Foley, 2004). This is done to overcome the barrier of raising the initial investment and running costs. While this is perceived as a good way to raise funds, if not well structured, it has the tendency to make the electricity market unsustainable. Example of this is the solar projects scheme (ProSolar) being carried out by GIZ in Kenya. Incentives for investment in mini-grid projects are through results-based financing intervention which is funded by the UK government (Makori, 2015). The scheme provides incentives to mini-grid project investors to create a market for mini-grid electricity generation. The scheme aim is to stimulate private sector participation. Another approach to funding mini-grid projects is through the financial and non-financial supports from micro-finance institutions. These schemes are limited due to lack of harmonisation between the financial institutions and the energy sector (Winiecki et al., 2008).

\subsection{Multi-criteria and Energy}

Energy problems analysis is often carried out under multi-criteria scenario in order to generate results that have practical implications (Haralambopoulos \& Polatidis, 2003; Tsoutsos et al., 2009; Kaya \& Kahraman, 2011). This has made the applications of multi-criteria multi-decision (MCMD) tools to gain wide acceptance among energy researchers and practitioners across the globe during decisionmaking process (Afgan \& Carvalho, 2002; Senguil et al., 2005; Streimikienė et al., 2016). Thus, generating the opportunity for the evaluation of energy problems from different perspectives. These tools are often applied under a situation where precise information is not available. Haralambopoulos and Polatidis (2003) reported how PROMETHEE II method can be used to address the problem of renewable energy projects in Greece. They considered the fuel saved, risk index, environmental index and job creation as evaluation criteria. Afgan and Carvalho (2002) considered the issue of renewable energy sources using simple additive weight method. Efficiency, installation cost, electricity cost, $\mathrm{CO}_{2}$ and area were used to simulate different cases for renewable energy source selection. Kahraman et al. (2009) investigated the use of a combined fuzzy axiomatic design and fuzzy Analytic Hierarchy Process

(AHP) as a tool for renewable energy alternatives selection. Technical, environmental, social-political and economic criteria were considered during the evaluation process.

Senguil et al. (2005) also considered these criteria during the evaluation of renewable energy supply systems by using a fuzzy TOPSIS approach. Kaya and Kahraman (2010) presented a dual study which dealt with the selection of an optimal renewable energy technology and the determination of the best among energy production sites in Istanbul, Turkey. The study used used VIKOR-AHP methodology as its methodology. AHP was used to determine the weights of the selection criteria. Kaya and Kahraman (2011) proposed model for appraising and choosing among various energy technologies alternative using modified fuzzy TOPSIS methodology. They evaluated the selection criteria weights using a by fuzzy pairwise comparison matrices. San Cristóbal (2011) applied VIKOR method in the selection of 
a renewable energy project. The result obtained showed that a biomass plant is the best alternative, closely followed by a wind generation $10<\mathrm{P}<50 \mathrm{MW}$ and solar thermo-electric alternatives. Kahraman and Kaya (2010) in another work suggested a fuzzy based multi-criteria decision-making approach to select the optimal energy policy using four main and 17 sub-main criteria and nine different energy investment alternatives. Streimikiene et al. (2016) presented a study on multi-criteria electricity generation technologies selection using Lithuania's power sector as a case study. The authors applied the AHP and Additive Ratio Assessment method (ARAS) for the ranking of the alternatives. In order to select an optimal energy mix, Malkawi and Azizi (2017) developed a model that assesses Jordan's electricity energy alternatives from a multiple criteria perspective. They evaluated various energy alternatives using several criteria clusters (economic, technical, environmental, ecological, social and risk assessment criteria). The electricity generation options evaluated include Oil and Natural Gas, oil shale generation, nuclear energy generation, wind generation, photovoltaic and concentrated solar power and biomass generation. Tsoutsos et al. (2009) utilised a multi-criteria methodology in planning for sustainable energy on the island of Crete in Greece. A group of energy planning options is determined by the implementation of installations of renewable energy sources on the island and is assessed against economic, technical, social and environmental criteria.

\section{Methodology}

The proposed framework for mini-grid business model selection is based on the concept of IT2FSs, CRITIC, TOPSIS and WASPAS methods.

\section{Table 1}

Selection criteria

\begin{tabular}{|c|c|}
\hline Criteria & Description \\
\hline i. Electricity tariff $\left(\mathrm{C}_{1}\right)$ & $\begin{array}{l}\text { An electricity tariff is a pricing structure which electricity companies use in billing } \\
\text { electricity consumer. It usually consists of the consumptive-based charges (kWh) } \\
\text { and demand charges ( } \mathrm{kVA}) \text {. }\end{array}$ \\
\hline ii. Energy Demand $\left(\mathrm{C}_{2}\right)$ & $\begin{array}{l}\text { This is the rate of electricity usage. It is the average value of power used over a } \\
\text { specified time interval. }\end{array}$ \\
\hline iii. Economic activity $\left(\mathrm{C}_{3}\right)$ : & $\begin{array}{l}\text { The demand for electricity is dependent on the level of economic activities in an } \\
\text { area. This influences the type of mini-grid business model that will successfully } \\
\text { manage the economic activities of an area. }\end{array}$ \\
\hline iv. Mini-grid technology $\left(\mathrm{C}_{4}\right)$ : & $\begin{array}{l}\text { This criterion refers to the type of generation technology suitable for a location. It } \\
\text { depends on the availability of resources (wind, river flow, solar irradiation) and } \\
\text { closeness to fuel for generators. }\end{array}$ \\
\hline v. Mini-grid sustainability $\left(\mathrm{C}_{5}\right)$ : & $\begin{array}{l}\text { This criterion includes an assessment which is based on a qualitative comparison } \\
\text { between the complexity of the technology, and the availability of experts to ensure } \\
\text { a suitable operating support mini-grid technology. }\end{array}$ \\
\hline $\begin{array}{l}\text { vi. Mini-grid maintenance } \\
\left(\mathrm{C}_{6}\right) \text { : }\end{array}$ & $\begin{array}{l}\text { This criterion covers the maintenance (electrical and mechanical) requirements for } \\
\text { a mini-grid }\end{array}$ \\
\hline vii. Project finance $\left(\mathrm{C}_{7}\right)$ : & $\begin{array}{l}\text { This criterion assesses the sources of project funding (national, international, and } \\
\text { government). }\end{array}$ \\
\hline viii. Operational finance $\left(\mathrm{C}_{8}\right)$ : & $\begin{array}{l}\text { This criterion evaluates the ability of mini-grid operators to source for funds in the } \\
\text { daily running of the system. }\end{array}$ \\
\hline $\begin{array}{l}\text { ix. Operational environment } \\
\left(\mathrm{C}_{9}\right) \text { : }\end{array}$ & $\begin{array}{l}\text { This criterion appraises the mini-grids damage to the environmental quality. It } \\
\text { shows the influence of the mini-grid on the environment. }\end{array}$ \\
\hline x. Operator's efficiency $\left(\mathrm{C}_{10}\right)$ : & This criterion takes into account the service delivery level of mini-grid operators. \\
\hline xi. Political instability $\left(\mathrm{C}_{11}\right)$ : & $\begin{array}{l}\text { This criterion examines the influence of political activities on a mini-grid business } \\
\text { of an area. }\end{array}$ \\
\hline xii. Service quality $\left(\mathrm{C}_{12}\right)$ : & $\begin{array}{l}\text { This criterion evaluates the quality of electricity an area enjoys from a mini-grid } \\
\text { business. }\end{array}$ \\
\hline
\end{tabular}

The functions of these tools are as follow: (i) IT2FSs is used to capture linguistic information into fuzzy numbers, (ii) CRITIC method is used to determine the criteria weights and (iii) TOPSIS and WASPAS methods are used to rank the business models. This study considered private $\left(\mathrm{M}_{1}\right)$, government $\left(\mathrm{M}_{2}\right)$, 
community-based $\left(\mathrm{M}_{3}\right)$ and public-private $\left(\mathrm{M}_{4}\right)$ business models for mini-grid operation using twelve criteria (Table 1).

\subsection{IT2FSs}

The inability of type-1 fuzzy set membership functions to incorporate uncertainty into its framework led to the introduction of type-2 fuzzy sets membership functions. However, this new type of fuzzy sets involves complex mathematics during its application (Kahraman et al., 2014). In order to ease type-2 fuzzy sets membership functions implementation burden, IT2FSs was introduced as a special case of type-2 fuzzy sets membership functions (Fig. 1). This type of fuzzy set has two membership degree values (Ghorabaee et al., 2017a).

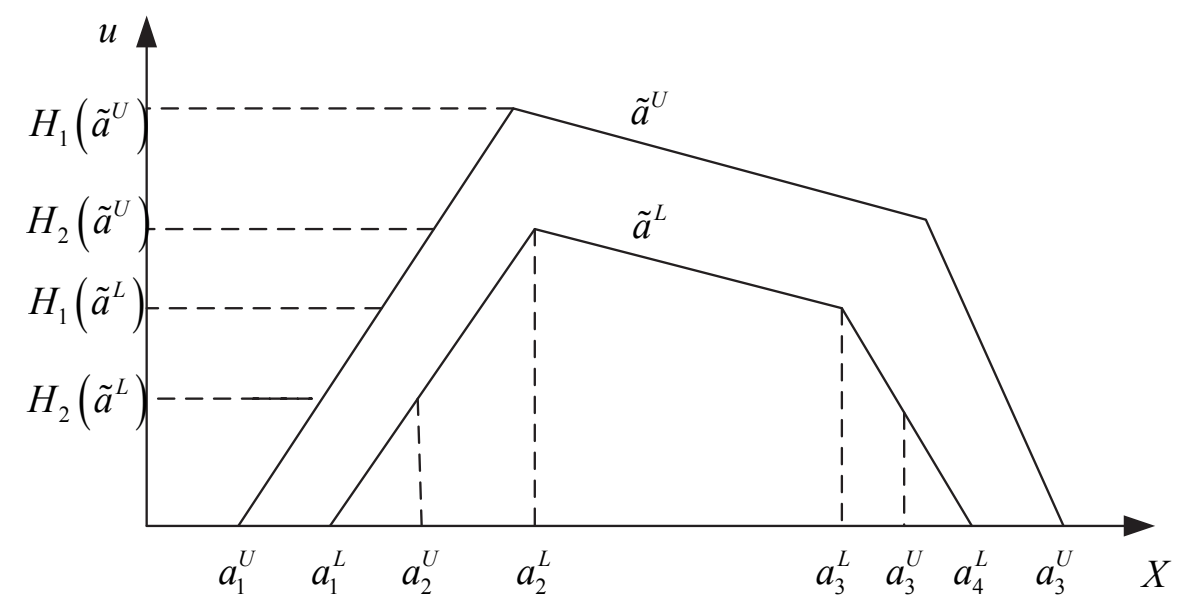

Fig. 1. A trapezoidal interval type-2 fuzzy sets (Ghorabaee et al., 2017a)

The explicit expressions for the two trapezoidal IT2FSs in Fig. 1 is given in Eq. (1) and Eq. (2). Kahraman et al. (2014) and Ghorabaee et al. (2017 a, b) reported that Eq. (1) and Eq. (2) can be subjected to different arithmetic operations (addition, multiplication and subtraction).

$$
\begin{aligned}
& \tilde{\tilde{A}}_{1}=\left(a_{11}^{U}, a_{12}^{U}, a_{13}^{U}, a_{14}^{U} ; H_{1}\left(\tilde{A}_{1}^{U}\right), H_{2}\left(\tilde{A}_{1}^{U}\right)\right), a_{11}^{L}, a_{12}^{L}, a_{13}^{L}, a_{14}^{L} ; H_{1}\left(\tilde{A}_{1}^{L}\right), H_{2}\left(\tilde{A}_{1}^{L}\right) \\
& \tilde{\tilde{A}}_{2}=\left(a_{21}^{U}, a_{22}^{U}, a_{23}^{U}, a_{24}^{U} ; H_{1}\left(\tilde{A}_{2}^{U}\right), H_{2}\left(\tilde{A}_{2}^{U}\right)\right), a_{21}^{L}, a_{22}^{L}, a_{23}^{L}, a_{24}^{L} ; H_{2}\left(\tilde{A}_{1}^{L}\right), H_{2}\left(\tilde{A}_{2}^{L}\right)
\end{aligned}
$$

The sum of two IT2FSs is expressed as Equation (3)

$$
\begin{aligned}
\tilde{\tilde{A}}_{1}+\tilde{\tilde{A}}_{2}= & \left(\left(a_{11}^{U}+a_{21}^{U}, a_{12}^{U}+a_{22}^{U}, a_{13}^{U}+a_{23}^{U}, a_{14}^{U}+a_{24}^{U}\right) ;\right. \\
& \left.\min \left(H_{1}\left(A_{1}^{U}\right) ; H_{1}\left(A_{2}^{U}\right)\right), \min \left(H_{2}\left(A_{1}^{U}\right) ; H_{2}\left(A_{2}^{U}\right)\right)\right) \\
& \left(\left(a_{11}^{L}+a_{21}^{L}, a_{12}^{L}+a_{22}^{L}, a_{13}^{L}+a_{23}^{L}, a_{14}^{L}+a_{24}^{L}\right) ;\right. \\
& \left.\min \left(H_{1}\left(A_{1}^{L}\right) ; H_{1}\left(A_{2}^{L}\right)\right), \min \left(H_{2}\left(A_{1}^{L}\right) ; H_{2}\left(A_{2}^{L}\right)\right)\right)
\end{aligned}
$$

The product of two IT2FSs is expressed as Equation (4) 


$$
\begin{aligned}
\tilde{\tilde{A}}_{1} * \tilde{\tilde{A}}_{2}= & \left(\left(a_{11}^{U} * a_{21}^{U}, a_{12}^{U} * a_{22}^{U}, a_{13}^{U} * a_{23}^{U}, a_{14}^{U} * a_{24}^{U}\right) ;\right. \\
& \left.\min \left(H_{1}\left(A_{1}^{U}\right) ; H_{1}\left(A_{2}^{U}\right)\right), \min \left(H_{2}\left(A_{1}^{U}\right) ; H_{2}\left(A_{2}^{U}\right)\right)\right) \\
& \left(\left(a_{11}^{L} * a_{21}^{L}, a_{12}^{L} * a_{22}^{L}, a_{13}^{L} * a_{23}^{L}, a_{14}^{L} * a_{24}^{L}\right) ;\right. \\
& \left.\min \left(H_{1}\left(A_{1}^{L}\right) ; H_{1}\left(A_{2}^{L}\right)\right), \min \left(H_{2}\left(A_{1}^{L}\right) ; H_{2}\left(A_{2}^{L}\right)\right)\right)
\end{aligned}
$$

The difference between two IT2FSs is expressed as Eq. (5)

$$
\begin{aligned}
\tilde{\tilde{A}}_{1}-\tilde{\tilde{A}}_{2}= & \left(\left(a_{11}^{U}-a_{21}^{U}, a_{12}^{U}-a_{22}^{U}, a_{13}^{U}-a_{23}^{U}, a_{14}^{U}-a_{24}^{U}\right) ;\right. \\
& \left.\min \left(H_{1}\left(A_{1}^{U}\right) ; H_{1}\left(A_{2}^{U}\right)\right), \min \left(H_{2}\left(A_{1}^{U}\right) ; H_{2}\left(A_{2}^{U}\right)\right)\right) \\
& \left(\left(a_{11}^{L}-a_{21}^{L}, a_{12}^{L}-a_{22}^{L}, a_{13}^{L}-a_{23}^{L}, a_{14}^{L}-a_{24}^{L}\right) ;\right. \\
& \left.\min \left(H_{1}\left(A_{1}^{L}\right) ; H_{1}\left(A_{2}^{L}\right)\right), \min \left(H_{2}\left(A_{1}^{L}\right) ; H_{2}\left(A_{2}^{L}\right)\right)\right)
\end{aligned}
$$

Ghorabaee et al. (2016) reported that the crisp value of an IT2FSs can be determined using Eq. (6).

$$
\begin{aligned}
& k(M)=\frac{1}{2}\left(\sum_{f \in\{U, L\}} \frac{a}{b}\right) \\
& a=a_{11}^{f}, a_{21}^{f}+\left(1+H_{1}\left(\tilde{A}^{f}\right)\right)\left(a_{12}^{f}, a_{22}^{f}\right)+\left(1+H_{2}\left(\tilde{A}^{f}\right)\right)\left(a_{13}^{f}, a_{23}^{f}\right)+a_{14}^{f}, a_{24}^{f} \\
& b=4+H_{1}\left(\tilde{A}^{f}\right)+H_{2}\left(\tilde{A}^{f}\right) \\
& \tilde{A}^{f}=\min \left(H_{x \in 1,2}\left(A_{1}^{f}\right) ; H_{x \in 1,2}\left(A_{2}^{f}\right)\right)
\end{aligned}
$$

\subsection{CRITIC method}

The initial step of CRITIC method deals with the normalisation of the crisp responses from decisionmakers. Each criterion is normalised on the basis of whether it is a benefit or non-benefit-based criterion. The normalisation expression for a benefit and non-benefit based criteria are given as Eq. (10) and Eq. (11), respectively.

$$
\begin{aligned}
& v_{i j}=\frac{x_{i j}-x_{\min , j}}{x_{\max , j}-x_{\min , j}} \\
& v_{i j}=\frac{x_{\max , j}-x_{i j}}{x_{\max , j}-x_{\min , j}}
\end{aligned}
$$

where $v_{i j}$ represents the normalised value of criterion $i$ with respect to response $j, x_{\max , j}$ represents the maximum value of criterion with respect response $j$, and $x_{\min , j}$ represents the minimum value of a criterion with respect to response $j$,

The normalised values of the various crisp values from the decision-makers are used to compute the criteria standard deviations (Eq. 12). 


$$
\sigma_{j}=\sqrt{\frac{\sum_{i=1}^{n}\left(x_{i j}-\bar{x}_{j}\right)^{2}}{n}} \forall j
$$

where $\bar{x}_{j}$ represents the mean value of criterion $j$.

A $m x m$ matrix for the normalised values correlation is constructed using Pearson correlation coefficient (Eq. (13)).

$$
\begin{aligned}
& R=\left[r_{j k}\right]_{m x m} \\
& r_{j k}=\frac{\sum_{i=1}^{m}\left(x_{i j}-\bar{x}_{j}\right)\left(x_{i k}-\bar{x}_{k}\right)}{\sqrt{\sum_{i=1}^{m}\left(x_{i j}-\bar{x}_{j}\right)^{2} \sum_{i=1}^{m}\left(x_{i j}-\bar{x}_{k}\right)^{2}}}
\end{aligned}
$$

This symmetric matrix information is combined with the standard deviation of the criteria to generate the information measures of the criteria in a decision matrix (Eq. 15).

$$
H_{j}=\sigma_{j} \sum_{k=1}^{K}\left(1-r_{j k}\right)
$$

The criteria information measures are used to obtain the various weights for the criteria in a decision matrix (Eq. (16)).

$$
w_{j}=\frac{H_{j}}{\sum_{k=1}^{K} H_{k}}
$$

\subsection{TOPSIS}

TOPSIS method is a leading multi-criteria tool in MCMD domain (Chen \& Hsieh, 2000; Ding, 2011; Ding \& Kamaruddin, 2015; Ighravwe \& Oke, 2017). Its wide acceptance is due to the fact that its framework considers the best and worst scenarios among sets of alternative in making a decision (Chen, 2000; Kaya \& Kahraman, 2011). Also, its framework has the capacity to analyse linguistic information. Given that most mini-grid information can be easily presented in linguistic terms, it makes TOPSIS a suitable tool to analyse the most suitable business model for a mini-grid business project. The implementation of TOPSIS using linguistic information is done under a fuzzy TOPSIS framework (Ighravwe \& Oke, 2017). This framework is similar to standard TOPSIS framework, but it makes use of fuzzy numbers during the first stage of its analysis.

This first stage of a fuzzy TOPSIS method is the design of a decision matrix. This is done using different information from decision-makers. This study uses a multiplication operation to aggregate decisionmakers responses (Eq. 1). The second stage of a fuzzy TOPSIS method involves the normalisation of the aggregated IT2FSs values. This is achieved by grouping the decision criteria into benefit and nonbenefit criteria. After which appreciate normalisation expression is considered. This study uses Eq. (17) and Eq. (18) to normalise the benefit and non-benefit criteria, respectively. The normalised results are used to construct a normalised decision matrix. 


$$
\begin{aligned}
\tilde{a}_{i j l} & =\left(\frac{\alpha_{i j}}{\delta_{j l}^{*}}, \frac{\beta_{i j}}{\delta_{j l}^{*}}, \frac{\tau_{i j}}{\delta_{j l}^{*}}, \frac{\delta_{i j}}{\delta_{j l}^{*}}\right) \\
\tilde{a}_{i j l} & =\left(\frac{\alpha_{j}^{*}}{\delta_{i j l}}, \frac{\alpha_{j}^{*}}{\tau_{i j l}}, \frac{\alpha_{j}^{*}}{\beta_{i j l}}, \frac{\alpha_{j}^{*}}{\alpha_{i j l}}\right) \\
\alpha_{j}^{*} & =\min \left(\alpha_{i j l}\right) \\
\delta_{j}^{*} & =\max \left(\delta_{i j l}\right)
\end{aligned}
$$

Based on the criteria normalised values, a weighted normalised decision matrix is formed. This entails combining the criteria weights and the criteria values in a normalised decision-matrix (Equation 21). The weighted normalised decision matrix is used to determine the distance of each solution from the positive and negative ideal solutions (Eq. (22) and Eq. (23)).

$$
\begin{array}{ll}
V_{i j}=w_{i j} r_{i j} & \forall i \in m \\
D_{i}^{+}=\sqrt{\sum_{j=1}^{n}\left(v_{i j}-v_{j}^{+}\right)^{2}} & \forall i \in m \\
D_{i}^{-}=\sqrt{\sum_{j=1}^{n}\left(v_{i j}-v_{i j}^{-}\right)^{2}} & \forall i \in m
\end{array}
$$

where $D_{i}^{+}$and $D_{i}^{-}$represent the positive and negative ideal distances of alternative $i$, respectively.

The criteria positive and negative ideal solution values are used to generate a closeness coefficient for each alternative (Equation 24). The alternative with the highest closeness coefficient is ranked as the most suitable solution for a problem (Equation 24).

$$
D_{l}=\frac{D_{l}^{-}}{D_{l}^{+}+D_{l}^{-}}
$$

\subsection{WASPAS method}

WASPAS method is among the frequently used multi-criteria tools. This is due to its simplified approach in identifying the most suitable alternative for a problem (Chakraborty \& Zavadskas, 2014). Basically, its structure depends on the use of normalised information in computing the weighted additive (Eq. (25)) and weighted product values of alternatives (Equation 26). The values from Eq. (25) and Eq. (26) are used to generate ranking indices for alternatives for a problem. This combination is subject to a controlling parameter whose value is within the range of 0 and 1 . The most suitable alternative for a problem is the alternative with the highest index (Eq. 27).

$$
\begin{aligned}
Q_{i}^{+} & =\sum_{j=1}^{n} x_{i j} w_{j} \\
Q_{i}^{-} & =\prod_{j=1}^{n} x_{i j}{ }^{w_{j}} \\
Q_{i} & =\lambda Q_{i}^{+}+(1-\lambda) Q_{i}^{-}
\end{aligned}
$$




\section{Application}

The proposed framework for the mini-grid business selection problem was applied in Nigeria. Three decision-makers were considered during the application of the proposed framework (Ghorabaee et al., $2017 \mathrm{a}, \mathrm{b})$. The questionnaire that was administered consists of two sections. The first section contains information on the importance of the criteria, while the second section deals with the impact of the mini-grid business models on the criteria. The linguistic expressions for responses in sections one and two are presented in Tables 2 and 3, respectively. During analysis of the criteria importance, subjective and objective weights (Ghorabaee et al., 2017a) were considered (Eq. (28)).

$$
w_{i}=\phi w_{s i}+(1-\phi) w_{o i} \text {, }
$$

where $w_{s i}$ and $w_{o i}$ represent the subjective and objective weights for criteria $i$, respectively, and $\phi$ represents contribution factor (Ghorabaee et al., 2017a).

\section{Table 2}

Linguistic terms and IT2FSs for the criteria weights

\begin{tabular}{lc}
\hline Linguistic terms & IT2FSs \\
\hline Highly unimportant & $(0.00,0.23,0.31,0.38,1,1),(0.00,0.15,0.23,0.30,1,1)$ \\
unimportant & $(0.31,0.38,0.46,0.53,1,1)(0.23,0.30,0.38,0.45,1,1)$ \\
Indecisive & $(0.46,0.53,0.61,0.68,1,1)(0.38,0.45,0.53,0.60,1,1)$ \\
Important & $(0.61,0.68,0.76,0.83,1,1)(0.53,0.60,0.68,0.75,1,1)$ \\
Highly important & $(0.76,0.83,0.91,0.98),(0.68,0.75,0.83,0.90,1,1)$ \\
Extremely important & $(0.91,0.98,1,1,1,1),(0.83,0.83,0.90,1,1,1)$ \\
\hline
\end{tabular}

\section{Table 3}

Linguistic terms and IT2FSs for the mini-grid business models evaluation

\begin{tabular}{lc}
\hline Linguistic terms & IT2FSs \\
\hline Very low & $(0.00,0.00,0.15,0.23,1,1),(0.05,0.10,0.15,0.20,0.9,0.9)$ \\
Low & $(0.15,0.23,0.30,0.38,1,1),(0.15,0.23,0.28,0.33,0.9,0.9)$ \\
Average & $(0.30,0.38,0.45,0.53,1,1),(0.28,0.38,0.43,0.48,1,1)$ \\
Above average & $(0.45,0.53,0.60,0.68,1,1),(0.43,0.53,0.58,0.63,0.9,0.9)$ \\
High & $(0.60,0.68,0.75,0.83,1,1),(0.58,0.68,0.73,0.78,1,1)$ \\
Very high & $(0.75,0.83,0.90,1.00,1,1),(0.73,0.83,0.88,1.00,1,1)$ \\
\hline
\end{tabular}

Based on the information obtained for the subjective weights (Table 4), the aggregated IF2FS subjective weights values for the criteria were calculated (see Table T2 in Ighravwe and Babatunde, 2018).

\section{Table 4}

Linguistic values of the criteria importance

\begin{tabular}{llcc}
\hline Criteria & $\mathrm{D}_{1}$ & $\mathrm{D}_{2}$ & $\mathrm{D}_{3}$ \\
\hline $\mathrm{C}_{1}$ & $\mathrm{EI}$ & $\mathrm{VI}$ & $\mathrm{VI}$ \\
$\mathrm{C}_{2}$ & $\mathrm{EI}$ & $\mathrm{VI}$ & $\mathrm{VI}$ \\
$\mathrm{C}_{3}$ & $\mathrm{VI}$ & $\mathrm{EI}$ & $\mathrm{VI}$ \\
$\mathrm{C}_{4}$ & $\mathrm{VI}$ & $\mathrm{I}$ & $\mathrm{VI}$ \\
$\mathrm{C}_{5}$ & $\mathrm{EI}$ & $\mathrm{VI}$ & $\mathrm{VI}$ \\
$\mathrm{C}_{6}$ & $\mathrm{EI}$ & $\mathrm{VI}$ & $\mathrm{VI}$ \\
$\mathrm{C}_{7}$ & $\mathrm{EI}$ & $\mathrm{I}$ & $\mathrm{VI}$ \\
$\mathrm{C}_{8}$ & $\mathrm{EI}$ & $\mathrm{I}$ & $\mathrm{VI}$ \\
$\mathrm{C}_{9}$ & $\mathrm{VI}$ & $\mathrm{VI}$ & $\mathrm{VI}$ \\
$\mathrm{C}_{10}$ & $\mathrm{VI}$ & $\mathrm{EI}$ & $\mathrm{VI}$ \\
$\mathrm{C}_{11}$ & $\mathrm{EI}$ & $\mathrm{EI}$ & $\mathrm{I}$ \\
$\mathrm{C}_{12}$ & $\mathrm{VI}$ & & $\mathrm{VI}$ \\
\hline
\end{tabular}

The values of the impact of the business models on the criteria were used to compute the criteria objective weights (Table 5). Eq. (4) and Table 5 information were used to determine the business models' IT2FS values (Tables T3 and T4 in Ighravwe and Babatunde, 2018). CRITIC method was used to compute the criteria objective weights. The subjective weights values were normalised in order to obtain a total weight value of 1 . The average subjective and objective weight values showed that 
electricity traffic and energy demand were the least and the most important criteria, respectively, for selecting a mini-grid business model. This observation is consistent with the objective weight method. The objective weight results identified energy demand and tariff as the most and least important criteria for mini-grid business models evaluation, respectively, for the case study. These results are not consistent with the subjective weight method. The subjective weight method results showed that there are ties among the most and least important criteria for the mini-grid business model evaluation (Table 6). Thus, the objective weight method is a better method for the mini-grid criteria weights determination. However, the combination of the subjective and objective weight methods showed that the average importance of the least and most important criteria are the same as that of the objective weight method (Sehgal et al., 2018).

\section{TOPSIS method results}

Based on how the questionnaire was constructed, all the criteria were considered as benefit-based criteria. By using the information in Tables T3 and T4 in Ighravwe and Babatunde (2018), the TOPSIS aspect of the proposed framework was implemented. First, the normalised values for were generated (Table T6 and Table T7 in Ighravwe and Babatunde, 2018). After which Eq. (4) was used to determine the crisp values for the information in Tables T6 and T7 (Ighravwe \& Babatunde, 2018), see Table Table T8 in Ighravwe and Babatunde (2018). The information in Tables 6 and Table T8 in Ighravwe and Babatunde (2018) was used to generate the weighted normalised crisp values for the business models (Table T9 in Ighravwe \& Babatunde, 2018). The positive and negative ideal solutions for the criteria were calculated using the information in Table T10 in Ighravwe and Babatunde (2018) and the results obtained are presented in Table 7.

Table 5

Linguistic values of the criteria importance

\begin{tabular}{|c|c|c|c|c|c|c|c|c|c|c|c|c|}
\hline & $\mathrm{D}_{1}$ & $\mathrm{D}_{2}$ & $\mathrm{D}_{3}$ & $\mathrm{D}_{1}$ & $\mathrm{D}_{2}$ & $\mathrm{D}_{3}$ & $\mathrm{D}_{1}$ & $\mathrm{D}_{2}$ & $\mathrm{D}_{3}$ & $\mathrm{D}_{1}$ & $\mathrm{D}_{2}$ & $\mathrm{D}_{3}$ \\
\hline Criteria & & $\mathrm{M}_{1}$ & & & $\mathrm{M}_{2}$ & & & $\mathrm{M}_{3}$ & & & $\mathrm{M}_{4}$ & \\
\hline $\mathrm{C}_{1}$ & $\mathrm{~L}$ & $\mathrm{H}$ & VL & $\mathrm{L}$ & AA & $\mathrm{VL}$ & $\mathrm{AA}$ & $\mathrm{H}$ & VL & $\mathrm{H}$ & $\mathrm{H}$ & VL \\
\hline $\mathrm{C}_{2}$ & $\mathrm{H}$ & AA & VL & $\mathrm{H}$ & $\mathrm{H}$ & VL & AA & $\mathrm{H}$ & VL & $\mathrm{AA}$ & $\mathrm{H}$ & VL \\
\hline $\mathrm{C}_{3}$ & $\mathrm{AA}$ & $\mathrm{VH}$ & $\mathrm{L}$ & $\mathrm{H}$ & AA & A & $\mathrm{H}$ & $\mathrm{H}$ & A & $\mathrm{H}$ & $\mathrm{H}$ & $\mathrm{L}$ \\
\hline $\mathrm{C}_{4}$ & AA & $\mathrm{H}$ & VL & A & AA & $\mathrm{L}$ & $\mathrm{H}$ & AA & $\mathrm{L}$ & AA & $\mathrm{H}$ & L \\
\hline $\mathrm{C}_{5}$ & $\mathrm{AA}$ & $\mathrm{H}$ & $\mathrm{L}$ & AA & AA & $\mathrm{L}$ & $\mathrm{H}$ & $\mathrm{AA}$ & $\mathrm{L}$ & $\mathrm{AA}$ & $\mathrm{H}$ & L \\
\hline $\mathrm{C}_{6}$ & AA & $\mathrm{H}$ & VL & AA & AA & VL & AA & $\mathrm{AA}$ & $\mathrm{L}$ & $\mathrm{AA}$ & $\mathrm{H}$ & $\mathrm{L}$ \\
\hline $\mathrm{C}_{7}$ & $\mathrm{AA}$ & $\mathrm{H}$ & VL & AA & AA & VL & $\mathrm{AA}$ & $\mathrm{AA}$ & VL & $\mathrm{AA}$ & $\mathrm{H}$ & L \\
\hline $\mathrm{C}_{8}$ & $\mathrm{H}$ & $\mathrm{H}$ & VL & $\mathrm{H}$ & AA & VL & $\mathrm{H}$ & $\mathrm{AA}$ & VL & $\mathrm{H}$ & $\mathrm{H}$ & VL \\
\hline $\mathrm{C}_{9}$ & $\mathrm{H}$ & AA & $\mathrm{L}$ & $\mathrm{H}$ & AA & $\mathrm{L}$ & AA & $\mathrm{AA}$ & $\mathrm{L}$ & $\mathrm{AA}$ & $\mathrm{H}$ & $\mathrm{L}$ \\
\hline $\mathrm{C}_{10}$ & $\mathrm{AA}$ & $\mathrm{H}$ & $\mathrm{L}$ & $\mathrm{AA}$ & $\mathrm{AA}$ & $\mathrm{L}$ & AA & $\mathrm{AA}$ & $\mathrm{L}$ & $\mathrm{AA}$ & $\mathrm{H}$ & L \\
\hline $\mathrm{C}_{11}$ & VL & $\mathrm{L}$ & $\mathrm{L}$ & VL & AA & VL & $\mathrm{L}$ & AA & A & $\mathrm{L}$ & $\mathrm{H}$ & VL \\
\hline $\mathrm{C}_{12}$ & $\mathrm{H}$ & $\mathrm{H}$ & $\mathrm{L}$ & $\mathrm{H}$ & $\mathrm{H}$ & $\mathrm{L}$ & $\mathrm{VH}$ & $\mathrm{VH}$ & $\mathrm{L}$ & $\mathrm{H}$ & $\mathrm{VH}$ & $\mathrm{L}$ \\
\hline
\end{tabular}

Table 6

Objective, subjective and average weights for the mini-grid business model criteria

\begin{tabular}{lccc}
\hline Criteria & Objective weights & Subjective weights & Average weights \\
\hline$C_{1}$ & 0.0551 & 0.0882 & 0.0717 \\
$C_{2}$ & 0.1309 & 0.0882 & 0.1096 \\
$C_{3}$ & 0.0844 & 0.0882 & 0.0863 \\
$C_{4}$ & 0.0709 & 0.0747 & 0.0728 \\
$C_{5}$ & 0.0729 & 0.0882 & 0.0805 \\
$C_{6}$ & 0.0630 & 0.0882 & 0.0756 \\
$C_{7}$ & 0.0807 & 0.0794 & 0.0801 \\
$C_{8}$ & 0.0807 & 0.0747 & 0.0777 \\
$C_{9}$ & 0.1231 & 0.0747 & 0.0989 \\
$C_{10}$ & 0.1107 & 0.0825 & 0.0966 \\
$C_{11}$ & 0.0625 & 0.0848 & 0.0737 \\
$C_{12}$ & 0.0651 & 0.0882 & 0.0766 \\
\hline
\end{tabular}


The ideal and negative ideal solutions for $\mathrm{C}_{6}$ and $\mathrm{C}_{7}$ are the same, while $\mathrm{C}_{10}$ had the same values for its ideal and negative ideal solutions (Table 7). The TOPSIS method showed that the most and least suitable mini-grid business model for the case study is private and government models, respectively (Table 7). To implement a private business model, there is a need for policy-makers to put infrastructure that will make mini-grid business to be attractive to investors in their energy sectors. For example, tax rebate, credit facility, comprehensive tariff scheme and security are among the issues that if properly handled will encourage investors to invest in a mini-grid business, especially in rural communities.

Table 7

Proportional distance of the mini-grid business models

\begin{tabular}{cccc}
\hline Models & $D_{i}^{+}$ & $D_{i}^{-}$ & $D_{i}$ \\
\hline$M_{1}$ & 0.00026 & 0.00043 & 0.61768 \\
$M_{2}$ & 0.00062 & 0.00011 & 0.15228 \\
$M_{3}$ & 0.00029 & 0.00025 & 0.46301 \\
\hline
\end{tabular}

\section{WASPAS framework results}

Based on the information in Table 8, the WASPAS framework was implemented. The WASPAS values for the business models were generated at $\lambda=0.5$ (Zavadskas et al., 2015). This method ranked private and community-based business model as the least and most suitable for mini-grid business models, respectively, for the case study (Table 8). The results obtained showed the TOPSIS and WASPAS methods results are not consistent (Fig. 2). Based on the results in Fig. 2, a government-based model should not be considered for a mini-grid business model in Nigeria, rather consideration should be given to a private or community-based business model. The selection of a community-based mini-grid business model is an attractive option for the current energy issues affecting Nigeria. This type of minigrid business model creates a sense of ownership among the members of a community. A well-managed community-based model does not only provide energy for a community, it creates energy export potential for a community. Thus, revenue can be generated to cater for other needs (education and health) within a community. Since most rural communities do not have the financial strength to kickstart a mini-grid project, they require financial aids from government and non-governmental organisations to finance this project.

These organisations can assist rural communities in the provision of technical assistance to set-up and maintain mini-grid projects. For example, a mini-grid project can be started by either a government or non-governmental agencies and hand-over to a community after a transition period. During the transition period, policies that will protect the interest of all the parties involved must be drafted by decision-makers. For example, there must be adequate security arrangements for experts that will setup and train people responsible for managing the mini-grid project. On the part of the community, the concession arrangement between them and the private firm must be well documented by experts. Policy on whether to allow a community-based or private business for a system can be studied using the concept of cost-benefit approach. This analysis will cover issues relating to mini-grid salvage value, job creation, return-on-investment, operation and maintenance cost.

Table 8

WASPAS results for the mini-grid business models

\begin{tabular}{cccc}
\hline Models & $Q_{1}^{j}$ & $Q_{2}^{j}$ & $Q^{\dot{1}}$ \\
\hline $\mathrm{M}_{1}$ & 0.4237 & 0.4202 & 0.4220 \\
$\mathrm{M}_{3}$ & 0.4066 & 0.6795 & 0.5431 \\
$\mathrm{M}_{4}$ & 0.4249 & 0.7085 & 0.5667 \\
\hline
\end{tabular}




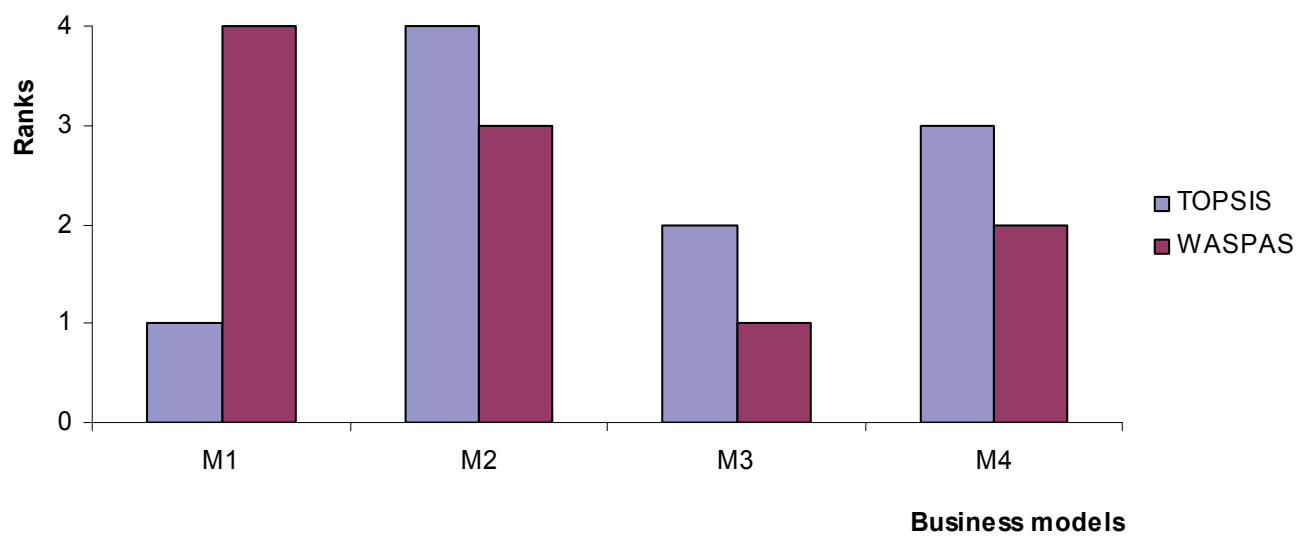

Fig. 2. Ranks of mini-grid business model using different methods

\section{Conclusions}

This study has laid the foundation for the use of IT2FSs in the analysis of mini-grid selection challenges (tariff, technology and risk). This was achieved by proposing a TOPSIS and a WASPAS frameworks for mini-grid business models ranking. These frameworks have the capacity to analyse mini-grid linguistic information. The framework were successfully applied to determine a suitable mini-grid business model for Nigeria. Based on the average values for a subjective and an objective weight methods, electricity traffic and energy demand were the least and the most important criteria, respectively, for selecting a mini-grid business model for the case study. The TOPSIS framework identified a private business model as the most suitable model for mini-grid, while this framework ranked a community-based, public-private and government business models as second, third and fourth, respectively. The WASPAS framework results showed that a community-based mini-grid model is the most suitable model, while this framework ranked a public-private, government and private business models as second, third and fourth, respectively.

One limitation of the proposed framework is that it cannot be used in selecting suitable mini-grid technology. Also, the model cannot be used to evaluate mini-grid sustainability for developing countries. These gaps can be addressed through further studies. The proposed approach can be applied to other energy study problems such as selection of renewable energy source and energy tariff.

\section{Acknowledgement}

The authors wish to acknowledge the assistance of Gbotemi Aloro of the Department of Psychology, University of KwaZulu Natal for her assistance in editing the article.

\section{References}

African Development Bank Group (2016). Green Mini-Grids in Sub-Saharan Africa: Analysis of Barriers to Growth and the Potential Role of the African Development Bank in Supporting the Sector http://www.energy4impact.org/sites/default/files/policy_briefing_-_mini-grid_final.pdf].

Afgan, N.H., \& Carvalho, M.G. (2002). Multi-criteria assessment of new and renewable energy power plants. Energy, 27(8), 739-755.

Akinbulire, T.O., Oluseyi, P.O., \& Babatunde, O.M. (2014). Techno-economic and environmental evaluation of demand-side management techniques for rural electrification in Ibadan, Nigeria. International Journal of Energy and Environmental Engineering, 5(4), 375-385. 
Akinyele, D. (2017). Techno-economic design and performance analysis of nanogrid systems for households in energy-poor villages. Sustainable Cities and Society, 34, 335-357.

Alzola, J.A., Vechiu, I., Camblong, H., Santos, M., Sall, M., \& Sow, G. (2009). Microgrids project, Part 2: Design of an electrification kit with high content of renewable energy sources in Senegal. Renewable Energy, 34(10), 2151-2159.

Anderson, T., Doig, A., Rees, D., \& Khennas, S. (1999). Rural energy services: a handbook for sustainable energy development. Intermediate Technology Publications Ltd (ITP).

Barnes, D., \& Foley, G. (2004). Rural electrification in the developing world: a summary of lessons from successful programs. Joint UNDP/World Bank Energy Sector Management Assistance Programme (ESMAP), World Bank, Washington, DC.

Bhattacharyya, S. C., \& Palit, D. (Eds.). (2014). Mini-grids for rural electrification of developing countries: analysis and case studies from South Asia. Springer.

Bonaccorsi, A., Giannangeli, S., \& Rossi, C. (2006). Entry strategies under competing standards: Hybrid business models in the open source software industry. Management Science, 52(7), 10851098.

Burmester, D., Rayudu, R., Seah, W., \& Akinyele, D. (2017). A review of nanogrid topologies and technologies. Renewable and Sustainable Energy Reviews, 67, 760-775.

Chakraborty, S., \& Zavadskas, E. K. (2014). Applications of WASPAS method in manufacturing decision making. Informatica, 25(1), 1-20.

Chen, C. T. (2000). Extensions of the TOPSIS for group decision-making under fuzzy environment. Fuzzy sets and systems, 114(1), 1-9.

Chen, S.H., \& Hsieh, C. H. (2000). Representation, ranking, distance, and similarity of LR type fuzzy number and application. Australian Journal of Intelligent Processing Systems, 6(4), 217-229.

Couture, T., \& Gagnon, Y. (2010). An analysis of feed-in tariff remuneration models: Implications for renewable energy investment. Energy policy, 38(2), 955-965.

Ding, J. F. (2011). An integrated fuzzy TOPSIS method for ranking alternatives and its application. Journal of Marine Science and Technology, 19(4), 341-352.

Ding, S. H., \& Kamaruddin, S. (2015). Assessment of distance-based multi-attribute group decisionmaking methods from a maintenance strategy perspective. Journal of Industrial Engineering International, 11(1), 73-85.

Franz, M., Peterschmidt, N., Rohrer, M., \& Kondev, B. (2014). Mini-grid Policy Toolkit: Policy and Business Frameworks for Succesful Mini-grid Roll Outs. GIZ.

Ghorabaee, M.K, Amiri, M., Kazimieras Zavadskas, E.K., \& Antuchevičienė, J. (2017a). Assessment of third-party logistics providers using a CRITIC-WASPAS approach with interval type-2 fuzzy sets. Transport, 32(1), 66-78.

Ghorabaee, M. K., Amiri, M., Zavadskas, E.K., \& Turskis, Z. (2017b). Multi-criteria group decisionmaking using an extended EDAS method with interval type-2 fuzzy sets.

Ghorabaee, M.K, Zavadskas, E.K., Amiri, M., \& Antucheviciene, J. (2016). A new method of assessment based on fuzzy ranking and aggregated weights (AFRAW) for MCDM problems under type-2 fuzzy environment.

GVEP International (2011). Policy brierfing: The history of mini-grid development in developing countries: http://www.energy4impact.org/sites/default/files/policy_briefing_-_mini-grid_final.pdf].

Haralambopoulos, D.A., \& Polatidis, H. (2003). Renewable energy projects: structuring a multi-criteria group decision-making framework. Renewable energy, 28(6), 961-973.

Hatziargyriou, N., Asano, H., Iravani, R., \& Marnay, C. (2007). Microgrids. IEEE power and energy magazine, 5(4), 78-94.

International Energy Agency (IEA). (2014). Africa energy outlook: A focus on energy prospects in SubSaharan Africa.

Ighravwe, D.E., \& Oke, S. A. (2017). A multi-hierarchical framework for ranking maintenance sustainability strategies using PROMETHEE and fuzzy entropy methods. Journal of Building Pathology and Rehabilitation, 2(1), 9. 
Ighravwe, D.E., \& Babatunde, O.M. (2018). Development of multi-criteria models for mini-grid management in developing countries. https://www.researchgate.net/publication/322331397_Data_for_minigrid business model evaluation

Kahraman, C., Oztayşi, B., Sarı, I. U., \& Turanoğlu, E. (2014). Fuzzy analytic hierarchy process with interval type-2 fuzzy sets. Knowledge-Based Systems, 59, 48-57.

Katiraei, F., Iravani, M. R., \& Lehn, P. W. (2005). Micro-grid autonomous operation during and subsequent to islanding process. IEEE Transactions on power delivery, 20(1), 248-257.

Kahraman, C., Kaya, I., \& Cebi, S. (2009). A comparative analysis for multi-attribute selection among renewable energy alternatives using fuzzy axiomatic design and fuzzy analytic hierarchy process. Energy, 34, 1603-1616.

Kahraman, C., \& Kaya, İ. (2010). A fuzzy multicriteria methodology for selection among energy alternatives. Expert Systems with Applications, 37(9), 6270-6281.

Kaya, T., \& Kahraman, C. (2011). Multicriteria decision making in energy planning using a modified fuzzy TOPSIS methodology. Expert Systems with Applications, 38(6), 6577-6585.

Kaya, T., \& Kahraman, C. (2010). Multicriteria renewable energy planning using an integrated fuzzy VIKOR \& AHP methodology: The case of Istanbul. Energy, 35(6), 2517-2527.

Kirubi, C., Jacobson, A., Kammen, D. M., \& Mills, A. (2009). Community-based electric micro-grids can contribute to rural development: evidence from Kenya. World development, 37(7), 1208-1221.

Knuckles, J. (2016). Business models for mini-grid electricity in base of the pyramid markets. Energy for Sustainable Development, 31, 67-82.

Krause, M., \& Nordström, S. (2004). Solar Photovoltaics in Africa: Experiences with financing and delivery models. Global Environment Facility.

Lasseter, R. H. (2002). Microgrids. In Power Engineering Society Winter Meeting, 2002. IEEE (Vol. 1, pp. 305-308). IEEE.

Makori, V.K. (2015). Effective Approaches of Monitoring Results-Based Financing Project (Doctoral dissertation, United States International University-Africa).

Malkawi, S., \& Azizi, D. (2017). A multi-criteria optimization analysis for Jordan's energy mix. Energy, 127, 680-696.

Martinot, E., Chaurey, A., Lew, D., Moreira, J. R., \& Wamukonya, N. (2002). Renewable energy markets in developing countries. Annual review of energy and the environment, 27(1), 309-348.

Polatidis, A. G., \& Conway, J. E. (2003). Proper motions in compact symmetric objects. Publications of the Astronomical Society of Australia, 20(1), 69-74.

Polatidis, H., Haralambopoulos, D. A., Munda, G., \& Vreeker, R. (2006). Selecting an appropriate multi-criteria decision analysis technique for renewable energy planning. Energy Sources, Part $B, 1(2), 181-193$.

Rolland, S. (2011). Rural electrification with renewable energy. Alliance for Rural Electification, Brussels.

San Cristóbal, J. R. (2011). Multi-criteria decision-making in the selection of a renewable energy project in Spain: The Vikor method. Renewable energy, 36(2), 498-502.

Sehgal, R., Mehrotra, D., \& Bala, M. (2018). Prioritizing the refactoring need for critical component using combined approach. Decision Science Letters, 7(3), 257-272.

Şengül, Ü, Eren, M., Shiraz, S.E., Gezder, V., \& Şengül, A. B. (2015). Fuzzy TOPSIS method for ranking renewable energy supply systems in Turkey. Renewable Energy, 75, 617-625.

Sindhu, S.P., Nehra, V., \& Luthra, S. (2016). Recognition and prioritization of challenges in growth of solar energy using analytical hierarchy process: Indian outlook. Energy, 100, 332-348.

Streimikienė, D., Šliogerienè, J., \& Turskis, Z. (2016). Multi-criteria analysis of electricity generation technologies in Lithuania. Renewable Energy, 85, 148-156.

Sun, C.C. (2010). A performance evaluation model by integrating fuzzy AHP and fuzzy TOPSIS methods. Expert Systems with Applications, 37(12), 7745-7754.

Tenenbaum, B., Greacen, C., Siyambalapitiya, T., \& Knuckles, J. (2014). From the bottom up: how small power producers and mini-grids can deliver electrification and renewable energy in Africa. World Bank Publications. 
Tsoutsos, T., Drandaki, M., Frantzeskaki, N., Iosifidis, E., \& Kiosses, I. (2009). Sustainable energy planning by using multi-criteria analysis application in the island of Crete. Energy Policy, 37(5), 1587-1600.

Ulsrud, K., Winther, T., Palit, D., Rohracher, H., \& Sandgren, J. (2011). The solar transitions research on solar mini-grids in India: Learning from local cases of innovative socio-technical systems. Energy for Sustainable Development, 15(3), 293-303.

Winiecki, J., Cortiglia, K., Morris, E., \& Chowdhary, S. (2008). Sparking Strong Partnerships: Field Tips from Microfinance Institutions and Energy Companies on Partnering To Expand Access to Energy Services. Washington, DC: Small Enterprise Education and Promotion (SEEP) Network and Sustainable Energy Solutions. SEEP Network \& Sustainable Energy Solutions.

World Bank (2008). Issues Note of the REToolkit: A Resource for Renewable Energy Development. Washington D.C.: World Bank.

Zavadskas, E.K, Bausys, R., \& Lazauskas, M. (2015). Sustainable assessment of alternative sites for the construction of a waste incineration plant by applying WASPAS method with single-valued neutrosophic set. Sustainability, 7(12), 15923-15936.

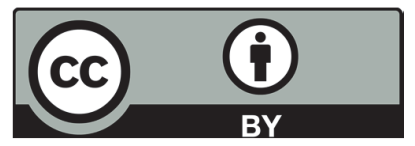

(C) 2018 by the authors; licensee Growing Science, Canada. This is an open access article distributed under the terms and conditions of the Creative Commons Attribution (CC-BY) license (http://creativecommons.org/licenses/by/4.0/). 